\title{
Three centuries of multi-storied St. Petersburg
}

\author{
Leonid Lavrov ${ }^{1}$, Fedor Perov ${ }^{1, *}$, Aleksandra Eremeeva ${ }^{1}$ and Vladimir Temnov ${ }^{1}$ \\ ${ }^{1}$ Saint Petersburg State University of Architecture and Civil Engineering (SPSUACE), 2-nd \\ Krasnoarmeiskaya St. 4, 190005, St. Petersburg, Russia
}

\begin{abstract}
The article is devoted to assessment of the role of high-rise buildings in the St. Petersburg historic city's ensemble. Features of formation of city architectural look, the conditions of city typical silhouette's appearance which is characterized by the contrast of a small number of high-rise structures with a low horizontal mass building are observed. The consequences of the emergence of a significant number of great height buildings, the silhouette of which conflicts with the traditional St. Petersburg landscape's compositional principles, are analyzed. The economic reasons of high-rise construction of residential and office buildings are given. The conclusions about the prospects of St. Petersburg high-rise construction in the light of city-building and economic factors are made.
\end{abstract}

\section{Introduction}

The problem of transformation of the historic St. Petersburg's specific silhouette, which evolved over three centuries, appeared at the beginning of the new century. The weakening of height regulations in the mid of 1990-ies allowed to place buildings up to a height of 2840 meters in the city center and in the depth of the districts which led to the fact that there are more and more objects in the classic urban panoramas, which destroy the "skyline" beauty.

The research urges to turn to the assessment of the role of high-rise structures in the ensemble of the historic St. Petersburg, the search for causes of spontaneous expansion of high-rise constructions at the turn of XX-XXI centuries, finding the ways for further effective management of Saint-Petersburg building activity on the basis of the lessons of the past and present. The scientific base of the research consists of the works of V. G. Lisovsky, S. V. Sementsov, P. Nikonov, dedicated to the history of St. Petersburg's architecture, stages of formation of urban spatial environment.

The history of regulation of St. Petersburg's building, including high-rise characteristic, has been examined in these works. A special place in the article is the analysis of the economic features of high-rise constructions in St. Petersburg. City-planning errors can't be corrected, but it is possible to adjust the further course of the St. Petersburg high-rise policy, to prevent the disappearance of the typical city silhouette.

\footnotetext{
*Corresponding author: dekanaf@gmail.com
} 


\section{Methods}

Methodological basis of the research is a comprehensive approach that includes study and generalization of literature and Internet sources on the history of high-rise construction in St. Petersburg; analysis of the legal framework regulating the height of the building for three centuries in the history of the city. The survey and photofixation of St. Petersburg's urban landscapes characterized by a pronounced silhouette were conducted; comparison of historical and modern city views, identifying the consequences of the current high-rise construction. The classification of buildings of St. Petersburg, exceeding the height of 100 $\mathrm{m}$ and functional affiliation of the building was made; the role of the buildings as urban dominants was defined.

\section{Results}

\subsection{The first high-rise building in Russia is an instrument of state policy}

The first high-rise building in St. Petersburg was built in 1712, when the city became the Russian capital. The city was only nine years old, and its buildings were mainly one-story wooden or wattle and daub constructions. They were lost among the stunted forest and did not violate the horizontality of the Neva Delta's landscape. Such image of the Northern capital did not meet the changed political situation. Peter I ordered to build a major stone Cathedral in the heart of the city, in the Peter and Paul's fortress, to replace the existing wooden one. The priority object for the Emperor was the high bell tower. Its architectural image had to reflect the idea of a new time, the appearance of Russia on the European arena. The works were headed by Domenico Trezzini. Lack of materials (bricks were brought from abroad partly), workers were escaping, but building continued. The stonework was 50 meters up, more lightweight wooden structures were used higher: the frame was mounted above them to accommodate the large clock and bell tower, and then the belfry. The installation of the spire's wooden framework was started at the height of 72 meters, which was prepared for the 1720-th year. The Cathedral's construction was completed in 1733. The cross on the top of the spire reached the height of 112 meters [1].

Even according to modern classification the bell tower could be considered as high-rise building. Its vertical was in contrast with the predominant horizontality of the city landscape and became a visual dominant on the banks of the Neva River. It surpassed the height of the Moscow Ivan the Great bell tower by one third and showed the potential of the "new" Russia. Cathedral's vertical exceeded the height of surrounding buildings in tentwenty times. The size of the Cathedral was paralleled only by the Twelve collegiums' building: the length of this government complex, was about 400 meters. Peter's enormous construction projects were implemented on "empty space". Two huge buildings (one was the Church building, another was the government) contrasted sharply with the environment and looked like structures transported from another world. There was nothing like this for hundreds of miles around. However, Peter I didn't have a chance to see the results of planned projects' implementation: he died in 1725 .

\subsection{From the XVIII to the XXI century. Regulation of horizontal position of Saint-Petersburg}

V. G. Belinsky wrote that "Petersburg, left by Peter the Great, was too poor and insignificant town to speak about it as something important, but its plans, its destiny was to last everlastingly" [2]. The presence of the huge constructions in the center had an 
enormous influence on the city urban development. Their appearance defined the image of the development for centuries to come. Contrast of the few high-rise buildings with calm horizontal lines and contour lines of low buildings had become the hallmark of St. Petersburg's silhouette. The useful legacy after Peter the Great was the special technique of strict control of the urban development process. Regulation of the height of buildings was one of the main directions, taking into account the level of technical building capacities, urban planning, compositional and social aspects.

The system of "exemplary" projects was the method of regulation during the reign of Peter the Great. It was supposed to build the houses for "eminent" people with a height of two storeys on sites in the town center (particularly on the embankments of the Neva River). In the peripheral areas projects of one or one and a half storeys houses applied.

With the city evolution, the degree of beautification was increasing, the development nature was changing. It became clear that the front parts of two-storey houses needed desired representation, therefore, it was decided to raise the height of buildings in the city center. In 1765 the Building Committee requested Catherine II to establish the height of 10 fathoms $(21,336 \mathrm{~m})$ for embankments' development that "buildings on the Neva bank at least a little match stony shore constructed on the River". In the same year, the rule to build houses of the same height along the street ("under the common cornice") was confirmed [3]. The first wave of existing buildings' completing was in 1820-1830-ies. Three or fourstorey houses dominated on Nevsky prospect in 1830; the height of buildings increased also in other critical areas. However, when five-storey residential buildings began to appear, City authorities decided to limit the private developers' ambitions. Nikolay I, who partly liberalized some aspects of St. Petersburg construction, found it necessary to stick to a strict line in relation to the height of the buildings. In 1844 the decree "On the restriction of the high buildings' construction in St. Petersburg, and limitation of the storey add-ins on existing buildings" was issued, according to which the height of private buildings was not to exceed the cornice of the Winter Palace, that is $23,47 \mathrm{~m}$ [4].

It should be noted that authoritative specialists considered it a more moderate parameter reasonable. They reminded that $\mathrm{K}$. Rossi had taken the mark of 22 meters to the buildings on Teatralnaya Street, and then recommended to stay within 21 meters for St. Petersburg (Fig. 1) [5].

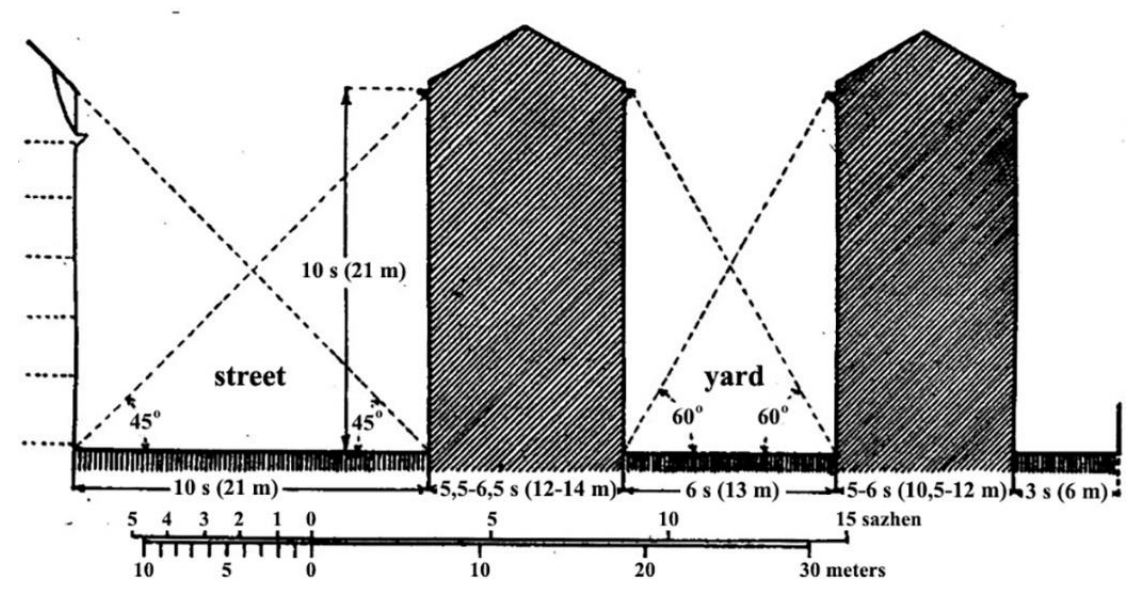

Fig. 1. Scheme of the distance between the city buildings and their height.

Orientation for this setting in combination with the rule of development "under the common cornice" were defining in urban planning in subsequent years as well. This rule was adhered to during the construction of new buildings both in the historic center and on 
the state highway of "socialistic" Leningrad - Moscovsky Avenue. When restoring destroyed buildings and repairing damaged ones, the desire to link their height with the eaves' level of adjacent buildings was decisive (house №16 on the Palace embankment, houses №19, №107, №184 on Nevsky prospect). The figures, set in 1844, remain a determining factor for the Central part of the city at the present time as well. Even with the reduction of protection zone, stipulated by the law of St. Petersburg №728-99 from 22.12.2005 about approving of the new General plan, they are obligatory on the territory of 1267 hectares [6].

\subsection{XIX century. Above 23.47 meters}

In Nikolay's decree deviations from the established level allowed, in particular during the construction of religious buildings. Church bell towers, steeples and domes, rising above the horizon, created the system of high-rise dominants in Saint-Petersburg. In 1857-1858 increasing the height of the bell tower of Peter and Paul's Cathedral at 10,5 meters was made (architect K. Ton, engineers - D. I. Zhuravsky, P. P. Melnikov, A. S. Rekhnevsky). When the spire's construction was changed and metal profiles were used instead of the wooden rafters, the height of the building became 122 meters. In 1809 it was decided to build a Church on St Isaac's square. Construction began in 1818 and lasted for 40 years. Foundation preparation was unique, it included more than 12000 piles with a length of 6,5 meters (however, later St. Isaac's Cathedral leaned over and settled on a few tens of centimeters).

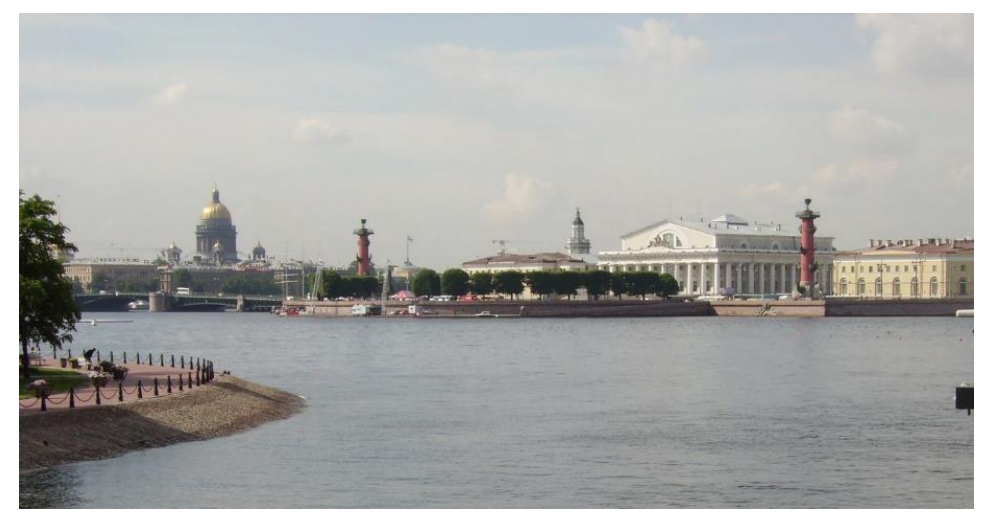

Fig. 2. St. Isaac's Cathedral in the panoramic view of Neva River.

New technologies applied in the mining and processing of various types of stones, which were used both for wall covering and for the columns' production. The main dome of the Cathedral was built with the use of metallic structures and shells. The gilding of the domes was performed by the method of "fire gilding", associated with the emergence of dangerous mercury vapor, which killed 60 artisans. It is considered that the total number of dead and injured on the construction site was a few tens of thousands of people. Construction costs exceeded 23 million of silver rubles, huge amount at that time [7]. Suffice it to say that it was spent over 400 kilograms of gold on the site [8]. With the advent of St. Isaac's Cathedral, St. Petersburg had acquired the second building exceeding a height of 100 meters. Its developed form was fundamentally different from the compact vertical of Peter and Paul's Cathedral. Important compositional center appeared in the silhouette of the city, which recognized the connection of two banks of Neva River (Fig. 2). 


\subsection{XX century. Deformation of "horizontal landscapes"}

In the late XIX century, increasing the height of buildings in the historic core of the city was allowed. The house of six stories high appeared downtown. In Soviet times the silhouette of the historical centre had lost a lot of the local verticals - Church domes and bell towers. Instead, in the 1930-ies only functionally necessary technical facilities were successfully built the way they were conceived, such as the water towers of the factory "Red nailer" (under the sketch of Y. G. Chernikhov). In the postwar years it was planned to build several residential buildings crowned with spires (in imitation of Moscow «Stalin skyscrapers»). The most significant realization was on the Moscow Prospect, near the Victory Park: by 1953 the height of the angular scope was increased and have crowned it with colonnade and the spire [9].

Since 1970-ies, 9-, 12 -, and partly 16-storey buildings, which supplanted typical fivestoreys in a short time, were being spread in the peripheral areas. Several 22-storey residential buildings were constructed in those places, where important urban compositions were being created - on Victory square, on Smolenka River's embankment. Over time, the inclusion of high-rise buildings in the city's skyline began to cause a public's negative reaction. The building of the 18-story hotel in the Western part of the Fontanka River evoked sharp criticism. Academician D. S. Likhachev found 52-meter high building "violating the typical Leningrad "skyline" [10].

The appearance of new high-rise peripheral areas and emergence of new lifestyle in 1970-80-ies were considered as inappropriate St. Petersburg traditions. Sociologists and hygienists drew their attention to the lack of proper hygienic conditions of the upper floor apartments. Difficulties with foundation construction began to appear. Ancient, strong enough soils lie at a depth of 20-30 m, and closer to the surface there are weak and heterogeneous water-saturated silty-clay soils. Such soils cause significant and differential subsidence of the buildings. It was not always possible to use piles up to 20-30 meters: in severe cases they were "sucked". In the 1970-ies the construction of the 18-storey tower on the Constitution square had to be stopped, as its foundation began to sink.

Significant impact on the silhouette of the city center was provided by new buildings of industrial and technical purposes. In 1962 the tallest building in the city appeared - the television tower. Its height was set by political reasons (Leningrad tower had to be higher than Eiffel tower in Paris). The disadvantage of the architectural appearance was some similarity of its proportions with the bell tower of Peter and Paul's Cathedral. It continued to remain the subject of pride in 2002 as well: in connection with the approaching 300th anniversary of St. Petersburg it was additionally highlighted in the panorama city with light illumination [11].

In 1973-1986 years another high-rise technical structure was built in the peripheral area (the architects Artushin B. I., Savin S.) - tower, which serves as a testing laboratory. Built of modern materials, it has a two-tier design concept, like the bell tower of Peter and Paul's Cathedral. Ferroconcrete wall, having the shape of a ring, raises from the ground up to $77 \mathrm{~m}$ and above is the antenna, reaching a height of $104,6 \mathrm{~m}$.

\subsection{After 1990 year: prestige, comfort, reliability and economy}

Since the mid 1990-ies the horizontal silhouette of the city historic core started to deform as well. Within the law "About the borders of areas of cultural heritage objects' protection on the territory of St. Petersburg and the usage mode of lands within the borders of the specified zones" the opportunity to place building up to a height of 28-40 meters in the depth of the blocks appeared [12]. Above the formed front cornice line, which still kept the traditional mark "not above 24 metres", mansard and intra corps were being appeared here 
and there. It was the market economy, where the key role was kept by construction firms and wealthy investors, backed by leading banks (Fig. 3).
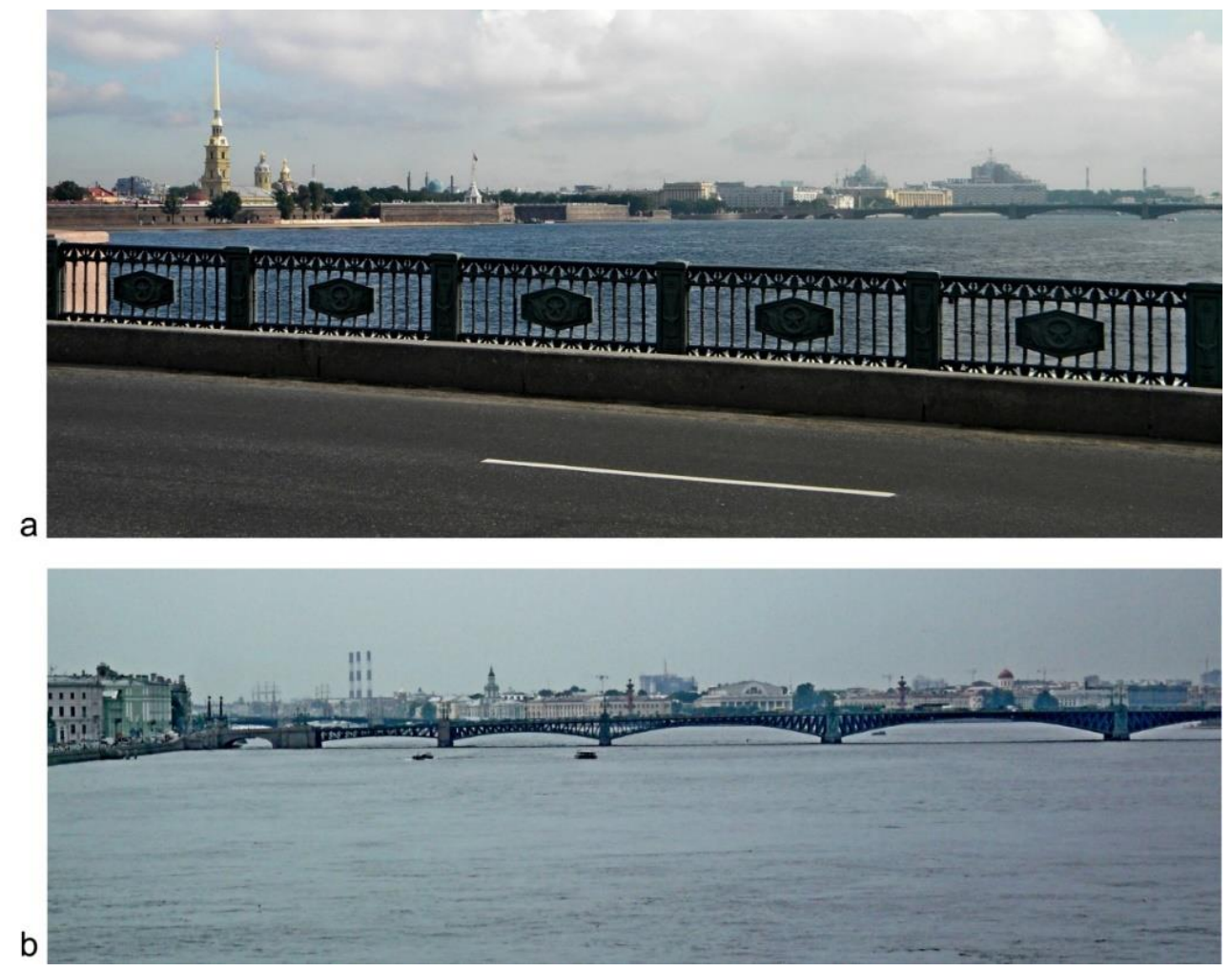

Fig. 3. Panoramas of the Neva, 2000 years: a - panorama of the North Bank of Neva River, $\mathrm{b}$ - panoramic view on the Strelka of Vasilyevsky island.

Modern technologies were quickly mastered, and residential buildings of 22-25 and more floors were used in new housing. However, by the early 2000 -s it became clear that doubts about the feasibility of high-rise building, that occurred in the 1970-s, had a number of reasons. It was understood that it is very difficult to construct a building of a great height: the technology of high-rise construction is very different from the standard one different foundation and different frame are required. Increasing wind loads and large amounts of energy should be considered. It's necessary to book additional electricity and heat supply from the city network, to install emergency power sources. Cost increase of high-rise building is also caused by expensive engineering and fire protection systems. The city emergency services should be also re-equipped (there was the experience in 1991 in Saint-Petersburg, when the fire in the hotel "Leningrad" killed 16 people. The victims could have been avoided if rescuers had mobile emergency stairs of necessary length).

There are more elevators and stairs in the high-rise building. As a result, the part of unsaleable areas is growing. According to "L1 Building company №1", in the construction of buildings higher than $75 \mathrm{~m}$, the cost of the project increases by $40-50 \%$ [12].

The cost of an apartment in multi-storey building in St. Petersburg was higher than in most European countries. It was recognized that "high-rise and low-rise buildings belong to different price ranges". Experts report that it is quite difficult to find a buyer for expensive apartments above the 17th floor, and the high-rise residential construction of more than 30 floors (i.e. above $100 \mathrm{~m}$ ) is economically inefficient [13]. 
In these conditions, leading developers and the administration began to show cautious about high-rise urban construction. In 2006 in St. Petersburg territorial building standards "Residential and public high-rise buildings. Saint-Petersburg" (TSN 31-332-2006) came into force [14], developed with the participation of specialists from SPSUACE. The standards apply to the construction of residential and public buildings up to $150 \mathrm{~m}$ (residential buildings with the height of more than $75 \mathrm{~m}$, public - more than $50 \mathrm{~m}$ ) and raise the questions of control, automation and mechanism of elevators, communication systems, design and architectural-planning decisions, fire prevention, systems of water supply and sewerage, bases and foundations. The implementation of some projects of high-rise buildings has been rejected, but some of them have been redesigned and realized in a shortened version [12].

\subsection{0-s. Apartments with panoramic view - commercial realization of the "horizontal landscape" potential}

Discussion about the reasonability of high-rise construction in St. Petersburg continues. Meanwhile now there are about 30 projects of residential buildings above 25 floors in the city in the implementation stage [12]. Investors take into account the exclusive attractiveness of luxury apartments with panoramic views of the city historic center. Unique horizontal position of Petersburg landscape reveals many architectural dominants from the height of «bird flight». Wealthy clients would pay well for the apartment, if it overlooks the dome of St. Isaac's Cathedral or Peter and Paul's fortress.

Story of the multifunctional complex "Mont Blanc" can be demonstrative. It began in 2003, when the corpus of the new building began to grow at the intersection of Neva and Small Nevka Rivers, just outside the two-storey building of the military hospital, built in the early XIX century, and the advertisement of luxury apartments appeared in the city, the important advantage of which was wonderful view of the wide panorama of the center. During the construction it became clear, what damage the invasion of the enormous building to the historic landscape made (Fig. 4).

In May of 2006, the City Planning Committee expressed their disagreement with the project of building "Mont Blanc" and announced that the new building irreversibly distorted the historical and architectural panorama of Neva banks. By that time, the height of the building was 74,5 meters, which exceeded the height of the bell tower of Peter and Paul's Cathedral. The attempt to make some adjustments to the architectural image of the facility (without reducing the height) was made, but it failed. The facility's construction was recognized as one of the worst urban planning mistakes of St. Petersburg. The financial results of sale of these apartments with panoramic view were never reported. Likely, opportunities to achieve similar economic effect are not exist currently - legal framework have changed, and places with such potential are not seen.

However, it is known, that apartments with the view in the residential complex "Premier Palace", where the surrounding landscapes are not comparable to the unique situation around "Mont Blanc", are 20-30\% more expensive than ordinary ones. "High-rise housing is oriented primarily to people with income far above the average. The apartments on the upper floors generally are more expensive than the same ones on lower floors" - the expert says $[12,15]$. 


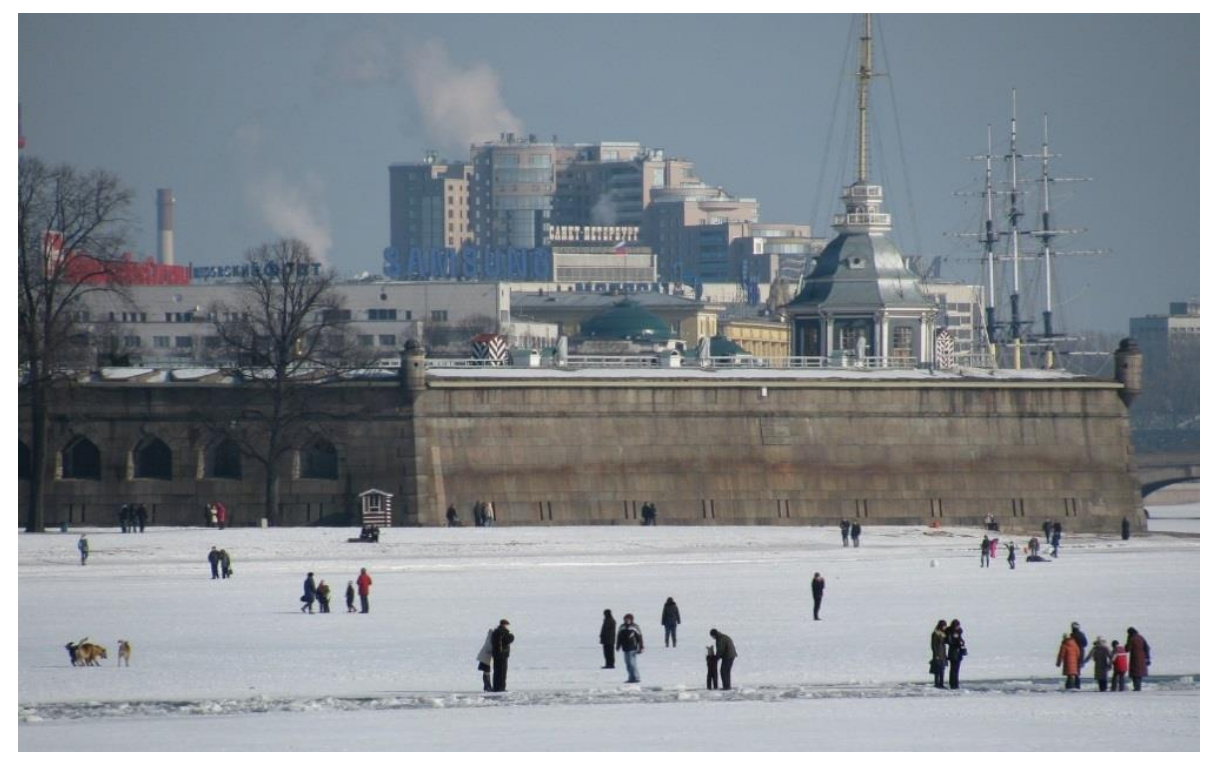

Fig. 4. View on Peter and Paul's fortress and the complex "Mont Blanc".

The problem of distortion of Saint-Petersburg's traditional silhouette has worsened since the beginning of the conversion of "industrial zone". "Industrial zone" began to emerge in the XIX century. At that time the territory of St. Petersburg was located only on the islands in the Neva Delta and was limited by Obvodny canal on the South. Subsequently, the city grew. Areas, which were considered peripheral previously, have appeared on the border with the center. Today they possess exceptional investment attractiveness. These areas lie outside the zone of UNESCO protection, the height regulations here are less strict what allows to build luxury houses with magnificent panoramic views of St. Petersburg's downtown. The lack of a unified conversion concept of the "industrial zone" led to the spontaneous development of individual sites. The "industrial zone" has grown up; the tall ring of parallelepipeds and towers began to form around the center of Saint-Petersburg.

\subsection{XXI century. High-altitude records of Saint-Petersburg}

The intention to build skyscraper with a height of 396 meters called "Okhta-center", close to baroque Smolny Cathedral, have caused an international protest. It was decided to hold an international design competition. The fierce public debate began. In July of 2006 the appeal of St. Petersburg Union of architects, who claimed that the skyscraper would destroy the image of the city, was published. This position was supported by the Russian Union of architects, noted that this contest violated all international and national rules. In protest, the Union of architects boycotted the competition. Three of the four invited foreign architects (N. Foster, K. Kurokava and R. Vinoli) got out of jury, expressed their negative attitude to a competitive task and paid attention on the danger of "aggressive effect of tall building on the city skyline". In June of 2007, the UNESCO session also negatively assessed the possible consequences of the emergence of high-rise housing on this place. In the end, the project was not implemented [16].

In 2011 «Gazprom» acquired a piece of land in the new district on the Northern shore of the Gulf of Finland. The skyscraper "Lahta-center" - the company's headquarters - is created at the distance of $9 \mathrm{~km}$ by air-line from the city historic center (Fig. 5). The authors of the project tried to shape the tower, resembling a silhouette of the bell tower of Peter and 
Paul's Cathedral: spire vertical monolith. Obviously, that the 462-metre tower with distinctive vertical silhouette will be perceived as dominant even against the backdrop of the prevailing 25-storey buildings. The large size of the structure is in tune with multikilometer aquatory of the Gulf of Finland - just as the vertical of Peter and Paul's Cathedral contrasted with 500-meter Neva River.

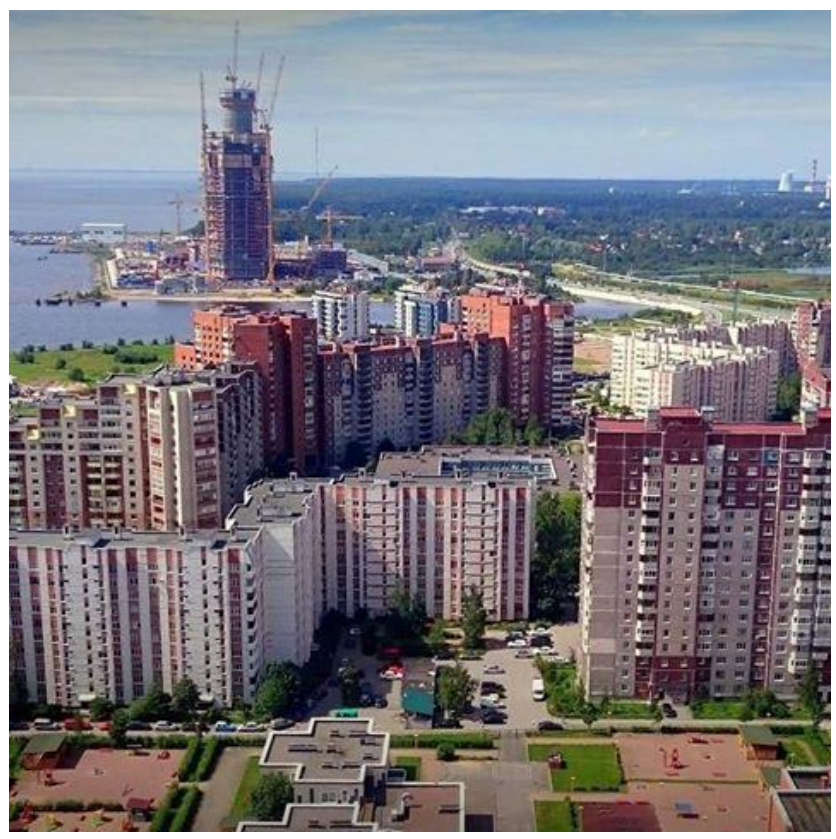

Fig. 5. The construction of a skyscraper "Lahta-center".

"Lahta-center" will be the unique building: other high-rise buildings in Saint-Petersburg are significantly conceded to it in many ways. The creators of this complex faced the same problems as the builders of St. Isaac's Cathedral, but more complicated. In accordance with this, equivalent architectural and technical decisions, regarding supporting structure, glass facades and engineering equipment, were developed and implemented. For example, the core of "Lakhta-center", in which emergency exits are, is able to withstand flame exposure during 4 hours without changing the properties of concrete and steel. The building is installed on 264 piles, each with a depth of 82 meters and with a diameter of 2 meters. In 2015, the project "Lahta-center" received "gold" certificate "LEED for Core \& Shell" on the complex's environmental efficiency [17].

By 2018 "Lahta-center" should reach 462 meters in height, and it will exceed by $1 / 3$ the highest European skyscraper «The Shard» in London. It is obvious, that the construction of such buildings is determined by prestige, among other things, and it will remain unique, like "Stalin's skyscrapers" in Moscow. It is possible to use buildings with a height of 100150 meters in St. Petersburg's further construction. The examples of such high-rise buildings are:

- "Leader tower" - the tallest office building in St. Petersburg. The skyscraper is located at a distance from the city center, but its silhouette can be seen from one of the three Central radial avenues. The building, compact in plan, was placed on the territory, where the 18-storey one was tried to build in Soviet times. The foundation of the Soviet high-rise construction was dismantled. Now, the observation platform, overlooking the historical center, is equipped on the last (42-nd) floor of the skyscraper; it is also possible to land helicopters there [18]. 
- The highest city residential complex "Prince Alexander Nevsky" is located far from the center, upstream of Neva Rover, right on the riverside. From the top floors apartments in a good weather you can see the Peter and Paul's fortress and St. Isaac's Cathedral. These are luxury apartments which cost more $\$ 1$ million [19].

The classification of buildings of St. Petersburg, exceeding a height of 100 meters, are presented in the Table 1.

Table 1. The classification of buildings of St. Petersburg, exceeding a height of 100 meters.

\begin{tabular}{|c|c|c|c|c|c|c|}
\hline $\begin{array}{l}\text { № } \\
\text { П/п }\end{array}$ & $\begin{array}{l}\text { Year of } \\
\text { Building }\end{array}$ & $\begin{array}{l}\text { Height, number } \\
\text { of floors }\end{array}$ & Name & Address & Function & Notes \\
\hline \multicolumn{7}{|c|}{$1703-1990$-s years } \\
\hline 1 & 1733 & $112 \mathrm{~m}$ & $\begin{array}{l}\text { Bell tower of } \\
\text { St. Peter and } \\
\text { Paul's } \\
\text { Cathedral }\end{array}$ & $\begin{array}{l}\text { St. Peter and } \\
\text { Paul's Fortress }\end{array}$ & $\begin{array}{l}\text { Religious } \\
\text { building }\end{array}$ & $\begin{array}{l}\text { after replacing the } \\
\text { construction of the } \\
\text { spire }(1858) \text { the } \\
\text { height reached } \\
122,5 \mathrm{~m}\end{array}$ \\
\hline 2 & 1958 & $101,5 \mathrm{~m}$ & $\begin{array}{l}\text { St. Isaac's } \\
\text { Cathedral }\end{array}$ & St. Isaac's Square & $\begin{array}{l}\text { Religious } \\
\text { building }\end{array}$ & \\
\hline 3 & 1962 & $\begin{array}{l}301,5 \mathrm{~m} \\
\text { (without } \\
\text { antenna) }\end{array}$ & TV tower & $\begin{array}{l}\text { Academic Pavlov } \\
\text { st., } 3\end{array}$ & $\begin{array}{l}\text { Technical } \\
\text { construction }\end{array}$ & $\begin{array}{l}\text { after the installation } \\
\text { of new antenna } \\
(2011) \text { the height } \\
\text { reached } 326 \mathrm{~m}\end{array}$ \\
\hline 4 & 1985 & $\begin{array}{l}77 \mathrm{~m} \text {, with } \\
\text { antenna } 105 \mathrm{~m}\end{array}$ & $\begin{array}{l}\text { Tower of CSII } \\
\text { RTC }\end{array}$ & Tikhorecky pr., 21 & $\begin{array}{l}\text { Technical } \\
\text { construction }\end{array}$ & \\
\hline \multicolumn{7}{|c|}{ after 1990 year } \\
\hline 5 & 2018 & $\begin{array}{l}462 \mathrm{~m}, \\
87 \text { floors }\end{array}$ & Lakhta-center & $\begin{array}{l}\text { near Lakhtinsky } \\
\text { spill }\end{array}$ & $\begin{array}{l}\text { Multifunctional } \\
\text { Complex }\end{array}$ & \\
\hline 6 & 2013 & $\begin{array}{l}145,5 \mathrm{~m}, \\
42 \text { floors }\end{array}$ & Leader Tower & $\begin{array}{l}\text { Constitucii Square, } \\
7\end{array}$ & Office Building & \\
\hline 7 & 2012 & $\begin{array}{l}126 \mathrm{~m}, \\
37 \text { floors }\end{array}$ & $\begin{array}{l}\text { «Prince } \\
\text { Alexander } \\
\text { Nevsky» }\end{array}$ & $\begin{array}{l}\text { Obukhovskoy } \\
\text { Oboroni pr., } 138\end{array}$ & $\begin{array}{l}\text { Residential } \\
\text { Building }\end{array}$ & \\
\hline 8 & 2009 & $\begin{array}{l}110 \mathrm{~m}, \\
27 \text { floors }\end{array}$ & «Atlantic-City» & $\begin{array}{l}\text { Savushkina st., } \\
126 \text { a }\end{array}$ & Office Building & \\
\hline 9 & 2003 & $\begin{array}{l}108 \mathrm{~m}, \\
25 \text { floors }\end{array}$ & «Bogatirsky, 2» & Bogatirsky pr., 2 & \begin{tabular}{|l|} 
Residential \\
Building
\end{tabular} & \\
\hline 10 & 2009 & $\begin{array}{l}105 \mathrm{~m}, \\
25 \text { floors }\end{array}$ & $\begin{array}{l}\text { «House near } \\
\text { Kommendant } \\
\text { Square» }\end{array}$ & $\begin{array}{l}\text { Komendantsky pr., } \\
13\end{array}$ & $\begin{array}{l}\text { Residential } \\
\text { Building }\end{array}$ & \\
\hline 11 & 2012 & $104,5 \mathrm{~m}$ & «Dominanta» & $\begin{array}{l}\text { Kosmonavtov pr., } \\
37 \mathrm{a}\end{array}$ & $\begin{array}{l}\text { Residential } \\
\text { Building } \\
\end{array}$ & \\
\hline 12 & 2012 & \begin{tabular}{|l}
$101 \mathrm{~m}$, \\
27 floors
\end{tabular} & \begin{tabular}{|l|} 
«Poem near \\
Three Lakes»
\end{tabular} & $\begin{array}{l}\text { Lunacharskogo pr., } \\
11-15\end{array}$ & $\begin{array}{l}\text { Residential } \\
\text { Building } \\
\end{array}$ & \\
\hline 13 & 2008 & $\begin{array}{l}100 \mathrm{~m}, \\
28 \text { floors }\end{array}$ & «Twin Peaks» & $\begin{array}{l}\text { Bukharestskaja st., } \\
110\end{array}$ & $\begin{array}{l}\text { Residential } \\
\text { Building }\end{array}$ & \\
\hline 14 & 2010 & $\begin{array}{l}100 \mathrm{~m}, \\
28 \text { floors }\end{array}$ & «Rainbow» & $\begin{array}{l}\text { Zagrebsky } \\
\text { boulevard }\end{array}$ & $\begin{array}{l}\text { Residential } \\
\text { Building }\end{array}$ & \\
\hline
\end{tabular}

St. Petersburg high-rise buildings can be divided into two groups:

1. The unique objects. There are three of them: the bell tower of Peter and Paul's Cathedral, St. Isaac's Cathedral and «Lahta-center».

Common features:

- their construction had not pragmatic incentive (it was not caused neither a necessity nor an expectation of economic benefit). These projects were justified by political or corporate challenges, 
- these objects' construction was not based on existing construction basis, it required study of advanced experience and innovative ideas (which required time and money),

- the silhouette of St. Isaac's Cathedral enriches the landscape of the city center, organically interacting with the surrounding buildings; dominant value of the bell tower of Peter and Paul's Cathedral and «Lahta-center» is determined by the contrast of their strongly pronounced verticality with the horizontal silhouette of the city,

- currently, the probability of emergence of equivalent structures is not visible.

2. "Ordinary" high-rise buildings (from 75 to 100 meters), which were total 353 on the 15th January of 2015:

- projects of residential buildings are calculated for commercial success, while for office buildings prestige is important,

- the decisive role in making profit is played by the specific view potential of the apartments, manifested at the level of the upper floors,

- the tendency of formation of characteristic volume-spatial solution of such buildings causes alertness. The investment calculations stimulate the release of maximum number of "view apartments". Projects of 25-30-storey buildings with a silhouette in the shape of a rectangle are born (like residential complex "Prince Alexander Nevsky"), or the groups of towers that conflict with the compositional basics of traditional St. Petersburg landscape (a small amount of vertical dominants over the horizontal low mass construction).

\section{Conclusion}

1. Formed over the centuries, the silhouette of the historic center is of exceptional value. It is characterized by the predominance of calm horizontals in combination with a small number of high-rise dominants. These traditional features have the strong impact on the perception of architectural solutions in Saint-Petersburg.

2. The experience in design, construction and operation of the residential high-rise buildings over the past decade has shown that the problems, emerging with increasing of the height of the buildings, had been underestimated both in St. Petersburg and in Russia.

3. Providing necessary sanitary-hygienic norms, required home comfort, the security of living in multi-storey apartment houses is possible only with significant expenses, which do not allow to attribute these buildings to mass housing type. The number of high-rise residential buildings will depend on the indicators of effective demand.

4. The greatest damage to St. Petersburg's silhouette is caused by "ordinary" high-rise buildings - residential and office complexes. Economic reasons (the desire to get more expensive view apartments in the crowning part of a tall building and, as a consequence, facades of rectangular shape) are in contradiction with the traditional St. Petersburg's formation (tower spire above the horizontal mass of the buildings).

5. At a moderate altitude, the interaction of old and new buildings through the silhouette's elaboration should be searched. However, we must remember that there have traditionally been not many dominants in Saint-Petersburg.

\section{References}

1. V. G. Lisovsky, Architecture of St. Petersburg, Three centuries of the history. St. Petersburg: AO Slaviya, 416 (2004)

2. URL: http://az.lib.ru/b/belinskij_w_g/text_1250.shtml (last accessed 28.02.2017) 
3. S. V. Sementsov, Stages of formation of the spatial environment of St. Petersburg. Bulletin of Civil Engineers, 2(7) (2006)

4. URL: http://www.nlr.ru/e-res/law_r/search.php?part=483\&regim=3 (last accessed 05.03.2017)

5. E. Y. Kupffer, Residential house: a guide for design and construction of modern dwellings, 273 (Moscow: M.O. Wolf, 1914)

6. URL: http://nikonovpn.spb.ru/?p=3298 (last accessed 06.03.2017)

7. URL:

https://ru.wikipedia.org/wiki/\%D0\%98\%D1\%81\%D0\%B0\%D0\%B0\%D0\%BA\%D0 $\%$ B8\%D0\%B5\%D0\%B2\%D1\%81\%D0\%BA\%D0\%B8\%D0\%B9_\%D1\%81\%D0\%B $\mathrm{E} \% \mathrm{D} 0 \% \mathrm{~B} 1 \% \mathrm{D} 0 \% \mathrm{BE} \% \mathrm{D} 1 \% 80$ (last accessed 05.03.2017)

8. URL: http://www.spb.aif.ru/culture/event/1187704 (last accessed 05.03.2017)

9. L. P. Lavrov, 1000 addresses in St. Petersburg: a short architectural guide, 416 (St. Petersburg: Eklektika, 2008)

10. D. S. Likhachev, "Skyline" of the city on the Neva River. Our Heritage, 1 8-13 (1989)

11. URL: https://en.wikipedia.org/wiki/Saint_Petersburg_TV_Tower (last accessed 05.03.2017)

12. URL: http://kommersant.ru/doc/2223512 (last accessed 27.02.2017)

13. URL: http://ppt.ru/news/106118 (last accessed 14.04.2016)

14. URL:

http://ohranatruda.ru/ot_biblio//normativ/data_normativ/47/47488/index.php (last accessed 08.02.2017)

15. URL: http://rway.ru/publication/publication71-2180.aspx (last accessed 07.05.2016).

16. URL: https://en.wikipedia.org/wiki/ Okhta_Center (last accessed 06.05.2016)

17. https://ru.wikipedia.org/wiki/Lakhta-tsentr (last accessed 0603 2017)

18. https://ru.wikipedia.org/wiki/lider-Tauer (last accessed 0603 2017)

19. https://ru.wikipedia.org/wiki/Kniaz_Aleksandr_Nevskii zhiloi_kompleks (last accessed 06.03.2017)

20. https://ru.wikipedia.org/wiki/Spisok_samykh_vysokikh_zdanii_Sankt-Peterburga (last accessed 28.02.2017) 